\title{
An Efficient Procedure for Deprotection of Acetals under Mild and Heterogeneous Conditions
}

\author{
BiBi Fatemeh Mirjalili," Mohammad Ali Zolfigol, ${ }^{\star}$ Abdolhamid Bamoniri, ${ }^{\ddagger}$ and Azizeh Hazar \\ Department of Chemistry; College of Science, Yazd Liviversity; P.O. Bor 89195-741. Yazd, Iran \\ "Department of Chemistry, College of Science, Bu-Ali Sina Liniversity. P.O. Box 4135. IIamadan 65/74, Iran \\ ${ }^{4}$ Department of Chemistry, College of Science, Kashan University, Kashan 51/67, Iran \\ Received December I, 2003
}

Key Words : Deprotection, $\Lambda$ cetal, $\Lambda \mathrm{l}\left(\mathrm{I}\left[\mathrm{SO}_{4}\right)_{3}, \mathrm{Mg}\left(\mathrm{ISO}_{4}\right)_{2}, \mathrm{NaI}_{1 \mathrm{SO}_{4}} \cdot \mathrm{II}_{2} \mathrm{O}\right.$

The electrophilicity of the carbonyl group is a dominant feature of its extensive chemistry. A major challenge in a multistep synthesis is to shield a carbonyl from nucleophilic attack until its electrophilic properties can be exploited. For this reason the protection and deprotection of the carbonyl functional group remain crucial challenges to organic chemists. Fxperience shows that the critical parameters are generally the stability and the cleavage of the protecting group rather than its introduction. As with most protecting groups, then many methods are available for the deprotection of acetals and ketals. A number of methods have been reported using Vanadyl(IV) Acetate, ' Cerium(III)Chloride,? Triphenylphosphine/carbontetrabromide, ${ }^{3}$ Ferric Chloride Hexahydrate, ${ }^{4}$ Silica Sulfuric Acid, ${ }^{5.6} \mathrm{Cu}\left(\mathrm{NO}_{3}\right)_{2} \cdot \mathrm{N}_{2} \mathrm{O}_{4}$, or $\mathrm{Fe}\left(\mathrm{NO}_{3}\right)_{3} \cdot 1.5 \mathrm{~N}_{2} \mathrm{O}_{4}{ }^{7}$ Pyridinium Poly(hydrogen fluoride) ${ }_{n}{ }^{8}$ $\mathrm{WCl}_{6,}{ }^{\circ} \gamma$ Picolinium chlorochromate, ${ }^{10}$ Decaboranc, ${ }^{11}$ Benzyl1riphenylphosphoniumperoxo-disulfate, ${ }^{12}$ and ctc.

Acids are the catalysts which are used the most in industry. including the lields of oil relining, petrochemicals and chemicals. They are responsible for producing more than $1 \times$ $10^{8} \mathrm{mt} /$ year of products. Among the lirst acid catalysts, the most commonly used were IJF, $\mathrm{I}_{2} \mathrm{SO}_{4}, \mathrm{HClO}_{4}$, and $\mathrm{I}_{3} \mathrm{PO}_{4}$ (in liquid form or supported on Keiselguhr). Solid acids have many advantages such as simplicity in handling. decreasing reactor and plant corrosion problems, and enviromentally safe disposal. ${ }^{13,14}$ Also, wastes and by-products can be minimized or avoided by developing cleaner synthesis routes. ${ }^{15}$ On the other hand, any reduction in the amount of sulfuric acid needed andior any simplification in handling procedures is required for risk reduction, economic advantage and environment protection. In addition, there is current research and general interest in heterogeneous systems because of the importance such systems in industry and in developing technologies. ${ }^{16}$ Very recently, we among many others have demonstrated that heterogeneous reagent systems have many advantages such as simple experimental procedures, mild reaction conditions and minimization of chemical wastes as compared to the liquid phase counterparts. ${ }^{23.27}$ Thus, inorganic acidic salts such as: $\mathrm{Al}\left(\mathrm{HSO}_{4}\right)_{3}^{17,18}$ $\mathrm{Mg}\left(\mathrm{HSO}_{4}\right)_{2}{ }^{19 \cdot 25}$ and $\mathrm{NaHSO}_{4} \cdot \mathrm{H}_{2} \mathrm{O}^{2.7-26}$ could be recommended for above mentioned purposes. Although there are a few

\footnotetext{
"Corresponding Author. e-mail: fmirjaliliayazduni.ac.ir
}

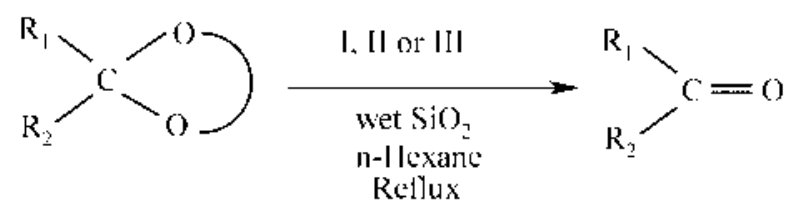

Scheme I

reports on the application of these salts in synthetic methodology, but only recently, more attention has been paid to the investigation of their potentials in organic synthesis. ${ }^{17-2 y}$ Now we wish to reporl a convenient method for deprotection of acetals or ketals using $\mathrm{Al}\left(\mathrm{ISSO}_{4}\right)_{5}$ (I), $\mathrm{Mg}\left(\mathrm{ISO}_{4}\right)_{2}$ (II) and $\left.\mathrm{NaI} \mathrm{ISO}_{4}\right]_{2} \mathrm{O}(\mathrm{III})$ in the presence of wet $\mathrm{SiO}_{2}$ (Scheme 1).

\section{Results and Discussion}

The conversion results of various acetals and ketals to their corresponding carbonyl compounds are presented in Table 1.

The products were isolated simply by filtering the reaction mixture and cvaporating the solvent from the lillerate.

As shown in Table 1, the ratio of the amount of reagent to substrate is as follow: $\mathrm{Al}\left(\mathrm{HSO}_{4}\right)_{3}<\mathrm{Mg}_{2}\left(\mathrm{HSO}_{4}\right)_{2}<\mathrm{NaHSO}_{4}$. By surveying of the results, it is clear that $\mathrm{Al}\left(\mathrm{HSO}_{4}\right)_{3}$ is the best one. Meanwhile, the deprotection rate of ketals is more than that of acetals (entry 3, 8, 13 in Table 1). In addition, the presence of an electron releasing group on acetal structure is as a reason for increasing the yield of deprotection (entry 9 and 11 in Table 1).

In conclusion, a cheap and easy procedure for the effective conversion of acetals and ketals to their corresponding carbonyl derivatives has been achieved. The cheapness and availability of the reagents, easy procedure and work-up make this method attractive for the large-scale operation.

\section{Experimental Section}

General: Chemicals were purchased from Fluka, Merck and Aldrich chemical companies. Acetals and ketals were synthesized in our laboratory. Deacetalization products were characterized by comparison of their spectral (IR, 'H-NMR), 
Table 1. Deacetalization of acetals and ketals with $\mathrm{Al}\left(\mathrm{HSO}_{4}\right)_{3}(\mathrm{l}) . \mathrm{Mg}\left(\mathrm{HSO}_{4}\right)_{2}$ ([I). or $\mathrm{NaHSO}_{4} \cdot \mathrm{H}_{2} \mathrm{O}$ (llI) in the presence of Wet $\mathrm{SiO} \mathrm{I}_{2}$ under mild and heterogeneous condition

\begin{tabular}{|c|c|c|c|c|c|}
\hline Entry & $\begin{array}{l}\text { Substrate } \\
\text { (A) }\end{array}$ & $\begin{array}{l}\text { Product } \\
\text { (B) }\end{array}$ & $\begin{array}{c}\mathrm{l}^{27} \\
\text { Time (min) } \\
\text { "Yield }(\%)\end{array}$ & $\begin{array}{c}\text { Il } \\
\text { Time (min) } \\
\text { "Yield }(\%)\end{array}$ & $\begin{array}{c}11 \mathbf{l}^{\circ} \\
\text { Time (miny/ } \\
\text { 'Yield }(\%)\end{array}$ \\
\hline 1 & & & $60 / 85$ & 60779 & 60775 \\
\hline 2 & & & $60 / 86$ & $50: 82$ & 60880 \\
\hline 3 & & & $60 / 85$ & $60 / 75$ & 60770 \\
\hline 4 & & & 6090 & 120885 & 60181 \\
\hline 5 & & & $60 \% 6$ & 6085 & 60184 \\
\hline 6 & & & $60 / 95$ & 6092 & 6090 \\
\hline 7 & & & $60: 87$ & $60 / 85$ & $50 / 80$ \\
\hline 8 & & & $35: 85$ & $60 / 83$ & $50 / 80$ \\
\hline 9 & & & 4090 & $45 / 85$ & $45 / 80$ \\
\hline 10 & & & $60 / 84$ & $60 / 70$ & 12066 \\
\hline 11 & & & $35: 92$ & 3090 & $36: 80$ \\
\hline 12 & & & 4090 & 40) 88 & 60770 \\
\hline 13 & & & $60 / 90$ & $60 / 85$ & $60 / 75$ \\
\hline 14 & & & $60) 93$ & 60) 85 & 60770 \\
\hline
\end{tabular}

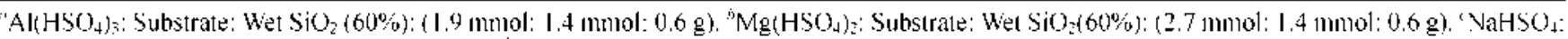
Substrate: Wet SiOn: (15 mmol: 1.4 mmol: 3 g). "isolated yields.

TLC and physical data with the authentic samples.

Deacetalization of the acetal (A11) to Vanillin (B11), a typical procedure: A mixture of the acetal A11 ( 1.4 mmole, $0.4 \mathrm{~g}), n$-Hexane $(15 \mathrm{~mL}), \mathrm{Al}\left(\mathrm{HSO}_{1}\right)=(1.9 \mathrm{mmol}, 0.6 \mathrm{~g})$ and wet $\mathrm{SiO}_{2}(\mathrm{w} / \mathrm{w}, 60 \%, 0.6 \mathrm{~g})$ were refluxed for $35 \mathrm{~min}$.
Reaction was monitored by TLC. After completion of the reaction. the mixture was filtered and the solid residue was washed with dichloromethane. Evaporation of the solvent gave the vanillin B11, $0.19 \mathrm{~g}(92 \%)$.

Acknowledgment. Financial support for this work by the 
research affairs, Yazd University. Yazd. Iran and also Bu-Ali Sina University. Hamadan. Iran, are gratefully achnowledged

\section{References}

1. Kantam, M. L.: Neeraja, V.: Sreekanth. P. Catal Commm. 2001. 2.301.

2. Marcantoni. E.: Nobili. F. J. Org Chem. 1997.62.4183.

3. Johnstone. C.: Kerr. W. J.: Scott. J. S. Chem. Conmm. 1996. 341.

4. Sen. S. E.: Roach, S. L.: Boggs. J. K. Ewing. G. J: Magrath. I. J. Org. Chem. 1997.62.6684.

5. Mijalili. B. F: Zolfigol M. A.; Bamoniri. A. J. Korean Chem. Soc. 2001. +5.546

6. Mirjalili. B. F.: Zolfigol. M. A.: Bamoniri. A. Molecules 2002.7. 751

7. Firouzabadi. H.: Iranpoor. N.: Zolfigol, M. A. Bull. Chem Soc. Jph. 1998,71.2169.

8. Watanabe, $Y:$ Kivosawa, Y: Tatsukawa. A.: Havashi. M. Tetrahedron Lett 2001. 42.4641 .

9. Firouzabadi. H.: Iranpoor. N.: Karimi. B. J. Chent. Res(S) 1998. 10. 664

10. Salehi. P: Khodaei, M. M.: Goodarzi. M. Russ, J. Org Chent. 2002, 38,1671

11. Lee, S. H.: Lee, I. H. Yoon. C. M. Tetrahedron Lett 2002. 43. 2699

12. Tajbaklısh. M.: Mohammadpoor-Baltork. I.: Ramazanian-Lehmali. F. J. Chent. Res (S). 2001. 5.185

13. Comma, A. Ciwrent Opinion in Solid State \& Materials Science: Current Chemistry: Ltd: 1997: Vol. 2. pp 63-75.

14. Coma, A.: Garcia, H. Cat. Today 1997, 38. 257.
15. Sikdar. S. K; Howell, S. G. Jounnal of Cleaner Production 1998. 6. 253

16. Sheldon. R. A.: Downing. R. S. Apphied Catalysis A: Genteral 1999. 189. 163

17. Salehi. P: Khodaei. M. M.: Zolfigol. M. A.: Sirouszadeh, S. Bull Chem. Soc. Jpn. 2003. 76. 1863

18. Zolfigol, M. A.; Ghorbani Choghamarani, A.; Tacjian-Nasab. A.; Keypour. H.: Salehzadeh. S. Bull. Korem Chem. Soc. 2003. 24. 638

19. Salehi. P: Khodaei. M. M.: Zoltigol. M. A.: Keyłant. A Montatsheffe Fur Cheme 2002, 133. 1291

20. Shirini, F.; Zolfigol, M. A.; Mallakpour. S. E.: Hajipour. A. R.: Baltork. I. M. Tetrahedron Lett $2002,43.1555$.

21. Salehi. P.: Khodaie. M. M.: Zolfigol. M. A.: Keyłan. A. Symh. Conmum. 2001. 31. 1947

22. Zolfigol. M. A.: Kiany-Borazjanii. M.: Sadeghi. M. M. Mohammadpoor-Baltork. I.: Memarian, H. R. Simth. Conmum. 2000. 30,3919 .

23. Zolfigol, M. A. Swhth Conmun. 2000. 30, 1593

24. Zolfigol. M. A.: Madrakian. E.: Ghaemi. E. Indian J. Chem. 2001. tOB. 1191

25. Zolfigol. M. A.: Kiany-Borazjani. M.: Mallakpour. S. E.: NasrIsfahani, H. Suth. Commm. 2000, 30.2573.

26. Zolfigol, M. A.; Kiany-Borazjani, M; Sadeghi. M. M.; Memarian. H. R. Mohammadpoor-Baltork. I. Synh. Conmmm. 2000. 30. 2945.

27. Asgarian-Damavandi. T.: Zolfigol. M. A.: Karami. B. Symth Conmum. 2001. 31.3183.

28. Li. X. C.: Wang. Y. L.: Wang. J. Y. Smb. Conmm. 2002. 32 . 2791 .

29. Li. X. C.: Wang, Y. L.: Wang, J. Y. J. Chin Chem Soc. 2002. 19. 397 